\title{
DOT-ELISA FOR EVALUATION OF HYDATID CYST WALL, PROTOSCOLECES AND HYDATID CYST FLUID ANTIGENS IN THE SERODIAGNOSIS OF CYSTIC ECHINOCOCCOSIS
}

\author{
S.R. SWARNA \& Subhash Chandra PARIJA
}

\begin{abstract}
SUMMARY
The aim of the present study is to evaluate cyst wall and protoscolex as an alternate source of antigen in serodiagnosis of cystic echinococcosis (CE). A total of 90 blood samples, 30 each of confirmed CE cases, disease controls and healthy controls were collected. Dot-ELISA using cyst wall, protoscolex and cyst fluid were used to demonstrate anti-hydatid antibodies. The sensitivity of Dot-ELISA using cyst wall, protoscolex and cyst fluid was $96.66 \%, 86.66 \%$ and $93.33 \%$ respectively and the specificity of the assay was $70 \%$ for Dot-ELISA using cyst fluid, protoscolex and cyst wall antigens. Results of the present study show that cyst wall and protoscolex can also be an useful source of antigen in detection of hydatid antibodies in the serodiagnosis of CE.
\end{abstract}

KEYWORDS: Cystic echinococcosis; Dot-ELISA; Cyst wall antigen; Serodiagnosis; Protoscolex antigen.

\section{INTRODUCTION}

Cystic echinococcosis (CE) is a zoonotic disease that is common in rural population of underdeveloped countries because of their close association with domestic and wild animals ${ }^{14}$. CE in human is mostly asymptomatic throughout the life in a majority of cases. In symptomatic cases, the clinical manifestations are highly variable and non-specific and depend on the organ infected with the cyst, number of the cysts, size of the cysts and their sites within the involved organ, interaction between the expanding cysts and adjacent organ, and complications caused by rupture of cysts ${ }^{19,24}$. Moreover, incubation period varies from few months to several years. Hence, there is difficulty in the clinical diagnosis of this condition.

In the absence of specific clinical features, early detection of the developing hydatid cyst in the cases depends more upon the laboratory procedures that is essential to initiate appropriate chemotherapy or surgery. Diagnosis of CE involves imaging methods, supplemented by immunological methods. Imaging methods in combination with immunological methods are now extensively used to support clinical diagnosis of the condition ${ }^{6,15,17,23}$. During the last two decades, tremendous advance has been made in both these fields, which have a direct bearing on the diagnosis of CE in humans as well as in animals.

Imaging methods are often too costly and are not available in most of the endemic areas. Thus, serodiagnosis plays the most important role in the diagnosis of $\mathrm{CE}$ because of their low cost and ease of performance. Serodiagnosis based on the detection of anti-
Echinococcus antibodies in the serum, remains the mainstay in the laboratory diagnosis of $\mathrm{CE}^{3,25}$.

Hydatid cyst fluid is the most commonly used source of antigen for detection of hydatid antibodies in the serum. Several serological tests using crude hydatid cyst fluid have been developed with considerable difference in both specificity and sensitivity for the diagnosis of $\mathrm{CE}^{5}$. Variation in sensitivity and specificity due to the difference in preparation of antigen and standardization of the technique has led to the use of newer metacestode antigens such as protoscolex antigen, cyst wall antigen and adult worm antigen in the diagnosis of $\mathrm{CE}^{4,9,18}$.

In the present study, Dot-ELISA, a simple and rapid microassay is used to evaluate cyst wall and protoscolex as source of antigen in the serodiagnosis of CE.

\section{MATERIALS AND METHODS}

Study groups: The present study is conducted in the Department of Microbiology of Jawaharlal Institute of Postgraduate Medical Education and Research (JIPMER) Hospital, Pondicherry. Samples are collected from the patients with CE, patients with other diseases, healthy students and blood donors. The informed consent is obtained from all human adult participants.

The Groups included:

Group 1 - Surgically confirmed and ultrasound diagnosed cystic 
echinococcosis $(n=30)$ : The group included 10 cases of surgically confirmed and 20 cases of ultrasound diagnosed cases of CE.

The cysts removed during surgery are confirmed to be of hydatid cyst etiology by histopathological evidence of germinal layer in the wall of the cyst and demonstration of protoscoleces and hooklets in the aspirated cyst fluid.

Ultrasound-diagnosed CE cases included non-operated cases of CE but diagnosed by ultrasonography. The cysts, which showed daughter cysts or prominent septation, and pathognomonic hydatid sands in cysts by ultrasound, are diagnosed as ultrasound-diagnosed CE.

Group 2 - Controls with other parasitic diseases $(\mathrm{n}=30)$ : This group included patients with other parasitic diseases other than $\mathrm{CE}$ like amoebiasis, filariasis, neurocysticercosis and toxoplasmosis.

Group 3 - Healthy controls $(\mathrm{n}=30)$ : This group included healthy adults (blood donors and students) who have not suffered from CE or any other disease in the recent past.

Serum: Five milliliters of venous blood is collected from all cases of surgically confirmed and ultrasound diagnosed CE $(n=30)$, controls with other parasitic diseases $(n=30)$ and healthy controls $(n=30)$ under aseptic precautions and is allowed to clot. The serum is separated and stored in duplicate at $-20{ }^{\circ} \mathrm{C}$ till use. Sodium azide $(0.05 \mathrm{~mol} / \mathrm{L})$ is used as preservative.

Preparation of somatic hydatid antigens: The hydatid cysts from the liver of human patients are collected after surgery. Three somatic antigen preparations are made from the same cysts and designated as hydatid cyst fluid (HCF) antigen, hydatid protoscolex (HPR) antigen, and hydatid cyst wall $(\mathrm{HCW})$ antigen.

1. Preparation of hydatid cyst fluid (HCF) antigen: The HCF antigen is prepared as per the method described by KANWAR et al. ${ }^{7}$. The HCF is aspirated aseptically from the fertile hydatid cyst and is collected in sterile centrifuge tube. The HCF is centrifuged at $1500 \mathrm{~g}$ for $30 \mathrm{~min}$ at $4{ }^{\circ} \mathrm{C}$, dialyzed extensively against distilled water. To this, $0.5 \mathrm{M}$ of phenylmethylsulfonyl fluoride (PMSF) is added at a proportion of $1 / 100$ and stored at $-20{ }^{\circ} \mathrm{C}$.

2. Preparation of hydatid protoscolex (HPR) antigen: The HPR antigen is prepared as per the method described by RAFIEI \& CRAIG $^{18}$. In this procedure, the $\mathrm{HCF}$ is centrifuged at $1500 \mathrm{~g}$ for $30 \mathrm{~min}$ at $4{ }^{\circ} \mathrm{C}$, and the sediment containing protoscoleces is collected in a sterile tube. The protoscoleces are washed three times with PBS 7.2. The washed protoscoleces are then subjected to three cycles of freezing and thawing and resuspended in 10 volumes of PBS 7.2 containing $0.5 \mathrm{M}$ PMSF (at a ratio of 1 in 100). The HPR suspension is then sonicated on ice in a 150w ultrasonic disintegrator, in 10-second bursts with five seconds intervals, until no intact protoscoleces are visible microscopically. The sonicate is left at $4{ }^{\circ} \mathrm{C}$ overnight and then centrifuged at $14,500 \mathrm{~g}$ for $30 \mathrm{~min}$. The supernatant is collected, dispensed in small aliquots and stored as HPR antigen at $-20^{\circ} \mathrm{C}$.

3. Preparation of hydatid cyst wall $(\mathbf{H C W})$ antigen: The HCW antigen is prepared as per the method described by RAFIEI \& CRAIG ${ }^{18}$.
After aspiration of $\mathrm{HCF}$, the collapsed $\mathrm{HCW}$ is washed three times in PBS 7.2 and homogenized using mortar and pestle. The homogenized tissue is collected in a sterile container and kept at $-20{ }^{\circ} \mathrm{C}$ overnight. Then, it is thawed and sonicated on ice in a $150 \mathrm{w}$ ultrasonic disintegrator, in $60 \mathrm{sec}$ bursts with ficccve second intervals, until no intact tissue bits are visible through naked eye. $0.5 \mathrm{M}$ of PMSF (at a ratio of 1 in 100) is added to the sonicated suspension and is left at $4{ }^{\circ} \mathrm{C}$ overnight and then centrifuged at $14,500 \mathrm{~g}$ for $30 \mathrm{~min}$. The supernatant is collected, dispensed in small aliquots and stored as HCW antigen at $-20{ }^{\circ} \mathrm{C}$.

Protein content of each antigen preparations is estimated by standard method of LOWRY ${ }^{8}$ and readings are taken at $660 \mathrm{~nm}$ in an UV-visible spectrophotometer (Cintra 5, Australia), aliquoted to $1 \mathrm{~mL}$ cryoprotected vials and stored at $-20{ }^{\circ} \mathrm{C}$.

Dot-ELISA: The Dot-ELISA is performed by using three different antigens (crude extract of HCW antigen, HPR antigen and HCF antigen) for the detection of IgG antibodies in the same batch of serum samples from cases of CE and controls. The optimization of Dot-ELISA conditions are performed to know the concentration of antigen to be dotted and the dilution of serum used.

Dot-ELISA using the HCF antigen for detection of antibodies consisted of following steps:

1 Antigen coating: A nitrocellulose membrane (NCM) (Hybond ECL, Amersham bioscience, Germany) of size $0.5 \times 0.5 \mathrm{~cm}$ is cut and mounted onto a plastic strip $(0.5 \mathrm{~cm} \times 5 \mathrm{~cm})$. A volume of $2 \mu \mathrm{L} /$ strip ( $5 \mu \mathrm{g} / \mathrm{strip}$ ) of HCF antigen is dotted on to individual strips and air dried for $30 \mathrm{~min}$

2 Washing: The un-adsorbed antigen is removed by washing the strips with washing buffer (sterile PBS 7.2 containing 0.1\% Tween-20 (PBS-T) is used as the washing buffer).

3 Blocking: The uncoated reactive sites in the strips are blocked by PBS 7.2 containing $2 \%$ BSA by incubating for three hours at $37{ }^{\circ} \mathrm{C}$ with constant shaking.

4 Washing: Strips are washed three times with PBS-T as described before.

5 Sample serum dilution and incubation: 1:1000 dilution of the patient sera is prepared in PBS-T and the strips are incubated for 1.5 hours at $37{ }^{\circ} \mathrm{C}$ with constant shaking.

6 Washing: The strips are washed three times with PBS-T as before to remove unbound antibodies in the sample serum.

7 Secondary antibody (conjugate) incubation: 1:2000 dilution of rabbit anti-human-IgG-HRP conjugated secondary antibody (Bangalore Genie, India) is used as per the manufacturer's instruction with PBS 7.2 containing Tween-20 (0.1\%) and incubated for 0.5 hours at $37{ }^{\circ} \mathrm{C}$ in the dark in a rocker shaker.

8 Washing: Strips are washed three times with PBS-T as before to remove unbound conjugate.

9 Colour development: Substrate solution is prepared freshly by adding $3 \mathrm{mg}$ of 3, 3' diaminobenzidine (DAB) (Sigma, USA) in 5 $\mathrm{mL}$ of PBS 7.2 containing $0.1 \%$ Tween- 20 and $5 \mu \mathrm{L} \mathrm{H}_{2} \mathrm{O}_{2}$ is added just before adding to the plastic tray. The strips are dispensed and incubated for $15-20$ minutes at $37^{\circ} \mathrm{C}$ in dark under constant rocking for the development of colour.

10 Stop reaction: The reaction is stopped by washing with double distilled water. 
The positive reaction is indicated by the development of brown coloured spot in 2 - 5 minutes. When the reaction is complete, the strips are washed with distilled water and allowed to dry. Once dried, the strips are stored in the dark.

The same Dot-ELISA procedure is repeated by using separately with $2 \mu \mathrm{L}$ of crude antigens of HPR and HCW antigens. The Dot-ELISA using all these antigens are tested for IgG antibodies in the same batch of serum samples from cases of $\mathrm{CE}$ and controls as mentioned earlier.

Statistical analysis: Sensitivity, specificity, positive predictive value (PPV), negative predictive value (NPV), and efficiency of the diagnostic methods are calculated as per the standard method ${ }^{16}$. Statistical difference between serological tests is compared by univariate statistical test, $\chi^{2}$ using Epi info 2001. In all these tests, a $p$-value of $<0.05$ is considered indicative of a statistically significant difference.

\section{RESULTS}

The results of Dot-ELISA using crude extract of HCW antigen, HPR antigen and HCF antigen for detection of hydatid antibodies in serum from the cases of CE and controls is summarized in Table 1.

An optimum concentration of $5 \mu \mathrm{g}$ separately of HCF, HPR and $\mathrm{HCW}$ antigen per dot could detect specific anti-hydatid IgG antibodies at 1:1000 serum dilutions of sera from CE cases.

Dot-ELISA using HCF antigen demonstrated diagnostic level of antibodies in 28 out of 30 (93.33\%) sera of confirmed cases of CE (GroupI). The test also detected antibodies in $43.33 \%$ sera of parasitic disease controls (Group-II) and 16.66\% sera of healthy controls (Group III).

Dot-ELISA using HPR antigen demonstrated diagnostic level of antibodies in 26 out of 30 (86.66\%) sera of confirmed cases of CE (GroupI). The test also detected antibodies in $40 \%$ sera of parasitic disease controls (Group-II) and 20\% sera of healthy controls (Group III).

Dot-ELISA using HCW antigen demonstrated diagnostic level of antibodies in 29 out of $30(96.66 \%)$ sera of the cases with confirmed CE (Group-I). The test also detected antibodies in $43.33 \%$ sera of parasitic disease controls (Group-II) and $16.66 \%$ sera of healthy controls (Group III).

\section{Table 1}

Detection of total $\mathrm{IgG}$ antibodies in serum of $\mathrm{CE}$ cases and controls by DotELISA using HCF, HPR and HCW antigens for diagnosis of cystic echinococcosis

\begin{tabular}{lccc}
\hline $\begin{array}{l}\text { Subject groups } \\
(\mathrm{n}=120)\end{array}$ & $\begin{array}{c}\text { Antibody positive in serum by } \\
\text { HCF }\end{array}$ & HPR & Dot-ELISA using \\
\hline $\begin{array}{l}\text { Confirmed cases } \\
(\mathrm{n}=30)\end{array}$ & $28(93.33 \%)$ & $26(86.66 \%)$ & $29(96.66 \%)$ \\
$\begin{array}{l}\text { Disease controls } \\
(\mathrm{n}=30)\end{array}$ & $13(43.33 \%)$ & $12(40 \%)$ & $13(43.33 \%)$ \\
$\begin{array}{l}\text { Healthy controls } \\
(\mathrm{n}=30)\end{array}$ & $5(16.66 \%)$ & $6(20 \%)$ & $5(16.66 \%)$ \\
\hline
\end{tabular}

Statistical analysis: The sensitivity, specificity, PPV, NPV and efficiency of the Dot-ELISA carried out with crude extract of HCW, HPR and HCF antigens for detection of hydatid IgG antibodies in serum are presented in Table 2.

\section{DISCUSSION}

Dot-ELISA is a highly versatile solid-phase immunoassay for antibody detection in the diagnosis of leishmaniasis ${ }^{11}$, toxoplasmosis ${ }^{13}$, malaria ${ }^{13}$, trypanosomiasis ${ }^{1}$, cysticercosis ${ }^{2}$ and $\mathrm{CE}^{22}$. The assay uses minute amounts of reagents dotted onto solid surfaces such as nitrocellulose or cellulose acetate membranes, which avidly bind proteins ${ }^{13}$. After incubation with antigen-specific antibody and enzyme-conjugated anti-antibody, the addition of a precipitable, chromogenic substrate causes the formation of a colored dot on the solid phase, which is visually read.

In the present study, the Dot-ELISA using HCW, HPR and HCF antigens separately, showed a sensitivity of $93.33 \%, 86.66 \%$ and $96.66 \%$ respectively, for detection of specific hydatid antibodies in serum (Table 2).

The sensitivity of Dot-ELISA obtained using HCF (93.33\%), HPR $(86.66 \%)$ and HCW (96.66\%) antigens separately in the present study is in agreement with the results of PAPPAS et al. ${ }^{11}$. In their study, DotELISA using sheep HCF antigens showed a sensitivity of $96 \%$ and specificity of $98 \%$. Cross-reactions were observed with sera from patients with cysticercosis, filariasis, toxocariasis, trichinosis, visceral larva migrans, and liver cirrhosis. Only one false-positive reaction was observed by the Dot-ELISA when 52 sera from healthy subjects were assayed. They observed that the Dot-ELISA is a rapid and economical enzyme immunoassay, which is very antigen-conservative, requires only nanogram quantities of parasite antigen and serum conservative and needs only 50 microliter of diluted patient serum ${ }^{12}$.

In another study, the bovine hydatid antigen was used to develop a simple and fast in vitro diagnostic assay for $\mathrm{CE}^{10}$. The procedure of DotELISA consisted of incubation of the serum sample with a textile colloidal dye (pink) and a nitrocellulose stick to which the hydatid antigen was bound. The presence of parasite-specific antibodies results in dyeing of the stick reactive area and appearance of a colored spot. Dot-ELISA showed positive results in all the patient sera and in none of the control sera. The test showed a good predictive value, allowing a speedy diagnosis of $\mathrm{CE}^{10}$.

Table 2

Diagnostic evaluation of Dot-ELISA for diagnosis of cystic echinococcosis

Diagnostic evaluation of Dot-ELISA for detection of hydatid antibodies

Diagnostic evaluation in serum using

\begin{tabular}{lccc} 
criteria & HCF & HPR & HCW \\
\hline Sensitivity & $93.33 \%$ & $86.66 \%$ & $96.66 \%$ \\
Specificity & $70 \%$ & $70 \%$ & $70 \%$ \\
Diagnostic efficiency & $88.33 \%$ & $83.33 \%$ & $90 \%$ \\
Positive predictive value & $60.86 \%$ & $59.09 \%$ & $61.70 \%$ \\
Negative predictive value & $92.59 \%$ & $85.71 \%$ & $96.15 \%$ \\
\hline
\end{tabular}


Dot-ELISA was also found to be $88.9 \%$ sensitive, $96.9 \%$ specific for rapid diagnosis of $\mathrm{CE}$ by demonstration of hydatid antibodies in the sera ${ }^{21}$.

In the present study, the specificity of Dot-ELISA is $70 \%$ using HCF, HPR and HCW antigens (Table 2). The moderate specificity obtained in the present study is due to cross-reaction with sera from neurocysticercosis, filariasis and amoebiasis. ROGAN et al. ${ }^{20}$ reported lower specificity (52\%) and higher sensitivity (97\%) with the use of crude sheep HCF. They have also observed cross-reactions with sera from patients with cysticercosis, filariasis, toxocariasis and trichinosis. It is suggested that the cross reaction was due to the use of a crude and complex HCF preparation containing shared helminth antigens ${ }^{22}$.

In the present study, the use of HCW and HPR antigens along with HCF antigens in Dot-ELISA for the diagnosis of CE showed that there is no significant difference in the sensitivity of Dot-ELISA $(p=0.785)$ using either of HCW, HPR and HCF antigens. No significant difference in the sensitivity of the Dot-ELISA by using HCW, HPR and HCF antigens, suggests that HPR and HCW could also be used as antigen apart from HCF, which is routinely used in the serodiagnosis of CE.

\section{RESUMO}

\section{Dot-Elisa para avaliação da parede do cisto hidático, protoscoleces e antígenos do fluido do cisto hidático no sorodiagnóstico da equinococose cística}

O propósito do presente trabalho é avaliar a parede cística e protoscolex como fontes alternativas de antígeno no sorodiagnóstico de equinococose cística (CE). De um total de 90 amostras de sangue, foram coletadas 30 de casos CE confirmados, 30 de controles de doença e 30 controles saudáveis. Dot-Elisa usando parede cística, protoscolex e fluido cístico foi utilizada para demonstrar anticorpos anti-hidáticos. A sensitividade de Dot-Elisa usando parede cística, protoscolex e fluido cístico foi de: $96,66 \%, 86,66 \%$ e $93,33 \%$ respectivamente e a especificidade do ensaio de $70 \%$ para Dot-Elisa usando fluido cístico, protoscolex e antígeno da parede cística. Resultados do presente estudo mostram que parede cística e protoscolex podem ser fontes úteis de antígeno na detecção de anticorpos hidáticos no sorodiagnóstico do CE.

\section{REFERENCES}

1. ARAUJO, F.G. - A method for demonstration of antibodies to Trypanosoma cruzi by using antigen-coated nitrocellulose paper strips. Amer. J. trop. Med. Hyg, 34: 242$245,1985$.

2. BISWAS, R.; PARIJA, S.C. \& NARAYAN, S.K. - Dot-ELISA for the diagnosis of neurocysticercosis. Rev. Inst. Med. trop. S. Paulo, 46: 249-252, 2004.

3. CRAIG, P.S. - Echinococcus granulosus: immunodiagnosis and vaccination, a perspective. Parassitologia, 39: 345-347, 1997

4. ERSFELD, K.; GASSER, R.B. \& CRAIG, P.S. - The immunodiagnostic potential of Echinococcus granulosus adult-worm antigens in human cystic echinococcosis. Parasit. Res., 83: 90-92, 1997

5. GOTTSTEIN, B. - Molecular and immunological diagnosis of echinococcosis. Clin. Microbiol. Rev., 5: 248-261, 1992

6. HARRIS, K.M.; MORRIS, D.L.; TUDOR, R.; TOQHILL, P. \& HARDCASTLE, J.O. Clinical and radiological features of simple hydatid cysts of the liver. Brit. J. Surg., 73: 835-838, 1986.
7. KANWAR, J.R.; KAUSHIK, S.P.; SAWHNEY, I.M. et al. - Specific antibodies in serum of patients with hydatidosis recognized by immunoblotting. J. med. Microbiol., 36: 46-51, 1992.

8. LOWRY, O.H.; ROSEBROUGH, N.J.; FARR, A.L. \& RANDALL - Protein measurement with the Folin phenol reagent. J. biol. Chem., 193: 265-275, 1951.

9. MAHMOUD, M.S. \& ABOU GAMRA, M.M. - Alkaline phosphatase from Echinococcus granulosus metacestodes for immunodiagnosis of human cystic echinococcosis. J. Egypt. Soc. Parasit., 34: 865-879, 2004.

10. MISTRELLO, G.; GENTILI, M.; FALAGIANI, P. et al. - Dot immunobinding assay as a new diagnostic test for human hydatid disease. Immunol. Lett., 47: 79-85, 1995.

11. PAPPAS, M.G.; HAJKOWSKI, R. \& HOCKMEYER, W.T. - Dot enzyme-linked immunosorbent assay (Dot-ELISA): a micro technique for the rapid diagnosis of visceral leishmaniasis. J. immunol. Meth., 64: 205-214, 1983.

12. PAPPAS, M.G.; SCHANTZ, P.M.; CANNON, L.T. Sr. \& WAHLQUIST, S.P. - Dot-ELISA for the rapid serodiagnosis of human hydatid disease. Diagn. Immunol., 4: 271 276, 1986.

13. PAPPAS, M.G. - Recent applications of the Dot-ELISA in immunoparasitology. Vet. Parasit., 29: 105-129, 1988.

14. PARIJA, S.C. \& SHEELA DEVI, C. - Current concepts in the diagnosis of cystic echinococcosis in humans and Livestocks and intestinal echinococcosis in canine hosts. J. vet. Parasit., 13: 93-102, 1999.

15. PARIJA, S.C. - Editorial - New approaches in the serodiagnosis of hydatid disease. J. Indian med. Ass., 92: 281-284, 1994.

16. PARK, K. - Textbook of preventive and social Medicine. 17. ed. Jabalpur, M/S Banarsidas Bharot publishers, 2002.

17. PAWLOWSKI, Z.S. - Potential eradication of taeniasis/cysticercosis. Parasit. today, 9: 464, 1993.

18. RAFIEI, A. \& CRAIG, P.S. - The immunodiagnostic potential of protoscolex antigens in human cystic echinococcosis and the possible influence of parasite strain. Ann. trop. Med. Parasit., 96: 383-389, 2002

19. REDDY, C.R.; NARASIAH, I.L.; PARVATHI, G. \& RAO, M.S. - Epidemiology of hydatid disease in Kurnool. Indian J. med. Res., 56: 1205-1220, 1968.

20. ROGAN, M.T.; CRAIG, P.S.; ZEYHLE, E. et al. - Evaluation of a rapid dot-ELISA as a field test for the diagnosis of cystic hydatid disease. Trans. roy. Soc. trop. Med. Hyg., 85: 773-777, 1991.

21. ROMIA, S.A.; YOUSSEF, M.E.; HANDOUSSA, A.E.; RIZK, H.M. \& SALLAM, S.M - Dot-ELISA as a diagnostic test in hydatid disease. J. Egypt. Soc. Parasit., 22: 603-610, 1992.

22. SCHANTZ, P.M. \& KAGAN, I.G. - Echinococcus (hydatidosis) In: HOUBA, V., ed. Immunological investigation of tropical parasitic disease. Edinburgh, Churchil Livingstone, 1980. p. 104-124.

23. SHARIFF, M. \& PARIJA, S.C. - Counter-current immunoelectrophoresis test for serodiagnosis of hydatid disease by detection of circulating hydatid antigen. J. microbiol. Meth., 14: 71-76, 1991.

24. VAMSY, M.; PARIJA, S.C. \& SIBAL, R.N. - Abdominal hydatidosis in Pondicherry, India. Southeast Asian J. trop. Med. publ. Hlth., 22(suppl.): 365-370, 1991.

25. ZHANG, W.; LI, J. \& McMANUS, D.P. - Concepts in immunology and diagnosis of hydatid disease. Clin. Microbiol. Rev., 16: 18-36, 2003.

Received: 20 January 2006

Accepted: 24 June 2008 